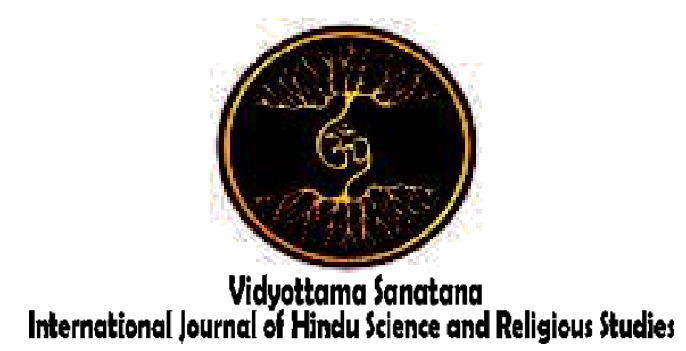

Vol. V No. 1 June 2021

\title{
IMPLEMENTATION OF TRI HITA KARANA VALUE THROUGH COMMUNITY SERVICE IN BATU BOLONG TEMPLE, WEST LOMBOK REGENCY
}

By:

I Wayan Agus Gunada ${ }^{1}$ I Made Ardika Yasa ${ }^{2}$

Insitut Agama Hindu Negeri Gde Pudja Mataram

Email: gunadastahngpmataram@gmail.com

Received: April 29, 2021

Accepted: June 30, 2021

Published: June 30, 2021

\begin{abstract}
The purpose of writing the results of community service is to give an overview of the implementation of activities carried out to express gratitude for the inauguration of IAHN Gde Pudja Mataram conducted by carrying out the dedication to the community in Pura Batu Bolong West Lombok Regency. This devotion also aims to implement the value and conception of Tri hita karana in the community. The conception of Tri hita karana is so full of noble values. However, the understanding of society that is still in the theoretical state needs to be developed and implemented so that the conception can be implemented in the state of practice of Hindu religious life. The method used is observation and study of libraries. While in this activity, the conception of Tri hita karana is a Hindu teaching that focuses on respect and appreciation to God, man, and the environment to achieve harmony and harmony of a happy life on all elements. Through the writing of the results of community service is expected to give a picture of the sublime conception of Tri hita karana and can be done a more in-depth review.
\end{abstract}

Keywords: devotion, implementation, tri hita karana, temple 


\section{INTRODUCTION}

As one of the official religions in Indonesia in its sacred teachings, Hinduism has many conceptions that become the basis of life for its adherents. Vedic as the source of dharma truth for Hindus is so sanctified and believed. Vedic as a Hindu scripture is classified in several forms, namely Vedic Sruti and Vedic Smrti. Vedic Sruti is a holy book where the Maha Rsi hear the holy word from Brahman. Revelation in the form of holy words is then written directly, known as Vedic Sruti. There is a large group division, namely Sruti Mantra, Brahmin, and Upanisad. While Vedic Smrti is a revelation written by the Maha Rsi based on the memory he once received and added interpretation where it consists of Smrti Wedangga and Smrti Upaweda (Nala \& Wiratmadja, 1991).

Based on Vedic scripture, the concepts of Hindu sacred teachings originated. These conceptions are related to ceremonial rites and all conceptions related to human life, one of which is the conception of Tri hita karana teachings. Wiana (2007) mentions that the conception of tri hita karana comes from three elements of the word 'tri' which means three, 'hita' which means happiness, and 'karana', which means cause, so in terminology, then tri hita karana means three things that cause happiness (Pradnyana et al., 2018). Tri hita karana, also in his conception, teaches that happiness is caused by harmony and harmony (Sunny, 2018).

This harmony is shown by understanding and implementing tri hita karana, namely parhyangan, pawongan and palemahan. Parhyangan is a harmonious relationship through respect and prostration to God Ida Shang Hyang Widhi Wasa, Pawongan is a harmonious and harmonious reciprocal relationship between fellow human beings, and Palemahan is the harmonization of life and respect and appreciation for the environment and the universe and its contents (Saitya, 2020).

Prostration bhakti to God Almighty can be done by performing yadnya ceremony, worship and implementation of the teachings of chess clan, harmonization between humans with awards can be done with respect and tolerance of this aspect then appears teachings tat twam asi, and appreciation to the natural environment and its contents can be done by keeping nature and its contents because without nature man will not be able to live, the destruction of nature has damaged the source of human life. Departing from the conception of the teachings of tri hita karana, the State Hindu Institute Gde Pudja Mataram carried out community service activities at Batu Bolong Temple in West Lombok Regency. Community service is one of the Dharma in Tri Dharma higher education carried out by a higher education institution. Community service is part of theoretical application activity in community practice where the theories taught in the educational process are applied and implemented (Yasa, 2021), not only limited to a scientific application activity but has the essence as an effort to participate educational institutions in the development of the nation's progress, especially the development and empowerment of the community through the implementation of theories.

This is what underlies community service activities by the State Hindu Institute Gde Pudja Mataram, namely to apply the conception of tri hita karana in elemental form. The Hindu sacred teachings are limited to theory in scripture alone and applied in elemental form in society. In addition, this devotional activity is a form of gratitude of the institution because it has officially changed its status from Gde Pudja Mataram State Hindu High School to Gde Pudja Mataram State Hindu Institute on Wednesday, December 16, 2020, through Presidential Regulation No. 21 of 2020.

This gratitude is realized by implementing community service activities entitled "Community Service as a Medium of Implementation of Tri hita karana," held at Batu Bolong Temple located in West Lombok Regency, West Nusa Tenggara Province on Tuesday, December 29, 2020.

There are three purposes of the implementation of this community service activity, namely as a form of dharma 
implementation that universities must carry out in helping and supporting the process of human resource development in the field of Hindu religion, the implementation of theory in practice, especially the application of the concept and value of tri hita karana teachings as a noble conception in Hinduism at the contextual level and its implementation in life and the third goal is the implementation of matur suksma on the official change of the form of institutions.

Related to that, a library is analyzed as a reinforcement of the conception of community service activities. In geguritan Candra bherawa, there is a conception of the practice of tri hita karana teachings, chess clan, color chess full of sacred values and plays a role in the formation and internalization of strengthening character education (Gunada, 2020). Budiasa et al. (1997) (in Budiasa et al., 1997) explained that tri hita karana is a conception of relationship harmony that causes happiness: the relationship of worship to God, human interaction, and environmental preservation. However, in geguritan sucita-subudhi, there is not directly gending that shows it. However, the conception of tri hita karana becomes an essential part of the noble values contained therein.

Giri explained that the formation of the child's character, in this case, the spiritual character, should be developed through the support and role of the family to shape the personality of the child who has the understanding and application of tri hita karana teachings, namely harmonization of respect for God, appreciation to fellow human beings and taking care of the environment (Giri, 2018).

Based on previous research studies, it can be concluded that the conception of tri hita karana is not only a conception but the teaching is even taught through artworks such as geguritan, where geguritan is a medium of Hindu religious learning, tri hita karana is also part of the teaching to strengthen character education, where all parties play a role in the process of strengthening character through harmonization of the human relationship with God, fellow human beings and the environment. Through this community service, the application of the theory is carried out so that the development of people's understanding is related to the implementation of the value in causing happiness of birth and mind.

Pragmatically the writing of the results of community service can be an overview of the efforts of higher education institutions. In this case, the State Hindu Institute Gde Pudja Mataram implements and grounded the existence of teachings and conceptions tri hita karana in the community as a form of participation in the development of the nation through the development of human resources in the field of Hindu religion and can be a literature study for studies on the conception of tri hita karana in the future.

\section{METHOD}

The writing of the results of community service uses two standard methods: the method of implementation of activities and research methods as steps of a study. The implementation method is carried out in three stages: planning community service, implementing community service, and evaluating the assessment of the results of community service activities.

This research uses qualitative research with a case study approach. Data sources in research on community service activities are in two forms: primary and secondary data sources, primary data sources in the form of notes collected through observations on the implementation of community service activities, and findings notes based on dialogue and questions and answers participating participants, in these activities. Meanwhile, the primary data sources are the results of literature studies related to and relevant to the research object, namely Tri hita karana, and the results of document studies collected during the activity.

The data collection method is done by using qualitative research type with case study approach model that is research with data used in the form of text descriptions. At the same time, case studies are a type of approach 
to qualitative research in exploring real-life limited by space and time (Creswell, 2015) It means that in research based on community service activities, the meaning of the case is an event at a specific location or time conducted by one or more subjects at the same time, namely events or community service activities carried out by the Hindu Religious Institute of Gde Pudja Mataram State in Pura Batu Bolong located in West Lombok Regency. The data is collected through data collection techniques conducted through observations and interviews, and document studies.

Observation is one of the data collection techniques conducted by observation. At the same time, the interview is a data collection technique used by in-depth dialogue with the source, and lastly is the study of documentation that analyzes the results of documentation in the form of images, video recordings, and books, as well as the results of reports relevant to the object discussed (Sugiyono, 2020)

Observations were conducted by looking at activities conducted during community service in Batu Bolong Temple, and interviews were conducted with several participants who participated in community service activities and analyzed the results of documentation during the activity. The data of the findings are then analyzed using triangulate techniques and confirmation to the community service committee to validate the validity of the data so that the results of research based on community service activities are objective following the circumstances in the field

\section{RESULT AND DISCUCCION}

Based on the findings through observations, interviews and literature studies, and documents during community service activities, it can be described the findings and results of the research as follows:

\section{Batu Bolong Temple in West Lombok Regency}

The island of Lombok, known as the island of Thousand Mosques, is one of the majority
Muslim areas, but there are also other religions such as Hinduism. Pura Batu bolong is one of several temples where Hindu worship is found in Lombok and is a testament to the history of Hinduism in Lombok. This is evidence that the social interactions of every religious adherent on the island of Lombok are maintained because of an understanding of harmony to lead to peace (Wirata, 2018).

In general, it can be described that Batu Bolong Temple is one of the temples as a place of worship for Hindus in Lombok, which is located in West Lombok. Pura Batu bolong stands on a rock in which there is a hole on the shore, and this characteristic makes the name of this temple called Batu Bolong temple.

The beautiful atmosphere on the edge of the beach makes the position of this temple quite strategic and has an aura of sacredness that makes the process of worship for Hindus so solemn. Generally, Hindus titayatra on Hindu holy days such as Purnama Day. Although it is a Hindu holy place, Batu Bolong temple is also one of the religious tourist destinations on the island of Lombok. A visit to Batu Bolong temple on Hindu religious holidays can reach hundreds of people, not only visited by Hindus to perform prayers but also to visit tourism (Damayanti \& Bagiastra, 2019).

So it can be concluded that the Batu Bolong temple in west Lombok regency that stands on the beach is proof that Hinduism develops and coexisted with the majority Muslim community and becomes evident that there is a harmonization of the social life of religious people on the island of Lombok. In addition to being a holy place for Hindus, Batu Bolong temple is also one of the tourist destinations that are religious tourism that is not only visited by Hindus but also foreign tourists from various religions.

\section{The conception of Parhyangan in community service activities}

In the context of the meaning of Tri hita Karana not only refers to the concept of worship to God Almighty alone but from the essence of Tri hita Karana itself can adapt and 
adapt in the ins and outs of life, one of which is education. The concept of tri hita Karana is part of the implementation process in education that supports the development of cognitive, affective, and psychomotor intelligence (Mustawan, 2020). This signifies that the teaching of Hinduism is the conception of Tri hita Karana not only on a rite level but also affects the whole area of life because the primary essence in the concept is how to harmonize and harmonize all elements of life both from the spiritualism side to Ida Shang Hyang Widhi Wasa. The emotional side of appreciation and respect for all human beings and concern for the surrounding environment and the natural environment supports human life.

The first conception in tri hita Karana is parhyangan; parhyangan has the meaning of relationship to God. Parhyangan is a harmonious relationship to Ida Sang Hyang Widhi Wasa because God is the origin of life, life is in God, and to God is the whole life again (Mustawan, 2020). In the context of the place, parhyangan refers to the understanding of temples or Hindu shrines. In contrast, in the context of ceremonies, parhayangan can be interpreted as a process or way to create a harmonious relationship to Ida Sang Hyang Widhi Wasa through yadnya and actions or activities that can show sraddha and bhakti to Ida Sang Hyang Widhi Wasa in Hindu teachings called catur marga.

The meaning of catur marga is formed from two syllables, namely 'catur', which means four, and 'marga', which means road, then etymologically catur marga is four paths, in the context of Hindu teachings that are four paths implemented by Hindus to get closer to Ida Sang Hyang Widhi Wasa (Haryani, 2016). These four paths in Hindu teachings are classified and distinguished based on the media taken and carried out, i.e., bhakti media through religious ceremonies called bhakti marga, media or implementation through sincere behavior and deeds without expecting a reward called karma marga, through the dissemination. Implementation and assessment of Vedic sacred sciences called jnana marga, and the last way through yoga, meditation, and semedi are called the king of marga yoga (Jayendra, 2017).

The four paths in the context of parhayangan on the state of yadnya are believed to bring Hindus close to God because the ultimate goal of Hinduism is moksha, mokshartam jagaditha ya ca iti dharma, true happiness obtained in the world and the hereafter, and united with Brahman. In community service conducted by the State Hindu Institute of Gde Pudja Mataram in Pura Batu Bolong West Lombok Regency, parhayangan is carried out with two forms, namely the concept of the place, namely Pura Batu Bolong, and the concept of the ceremony by carrying out joint worship as a form of implementation of Bhakti Marga.

The purpose of this joint prayer is not the only routine. However, it has the purpose as a thank you to Ida Sang Hyang Widhi for providing health and safety for the universe, and pleading for the universe in a state of peace and the main goal is a plea and gratitude for having run smoothly and the successful journey of changing the form of the institution of Gde Pudja Mataram State Hindu High School into the Gde Pudja Mataram State Hindu Institute.

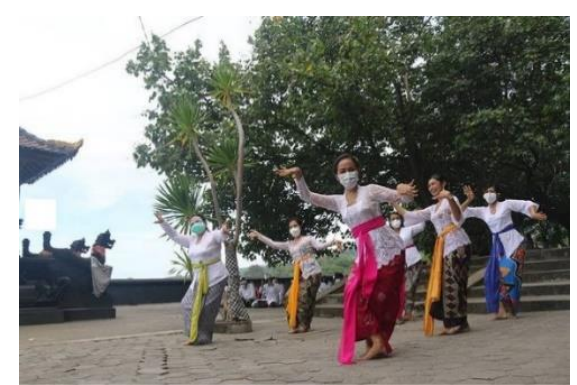

Picture 1. Ngayah Rejang Renteng by

Civitas Akademika IAHN Gde Pudja Mataram

Documentation IAHN Gde Pudja Mataram

Prayer in the context of Hindu teachings is not just a ritual of respect, but the essence is to draw closer to the creator (Rahayu, 2020). In worship, praying bhakti through muspa activities conducted with the beginning of ngayah dance Rejang renteng by academic community IAHN Gde Pudja Mataram then continued with tri sandhya and panca sembah. 
Rejang renteng dance is one of the guardian dances in the tradition of Hindu religious rites in Bali. Judging from the history of Rejang renteng dance is a dance that has been reconstructed by the Bali Cultural Service in 1999 assisted by Ida Ayu Made Diastini; this dance initially came from Nusa Penida. Furthermore, as a wali and bebali dance, this renteng rejang dance is a complement to the ceremony of the god yadnya as a form of bhakti offering to Ida Sang Hyang Widhi Wasa (Haryati \& Putra, 2019; Wahyuni \& Putra, 2020)

So it can be concluded that in community service to the concept of parhyangan, which begins with ngayah Rejang renteng dance is a form of respect, bhakti offerings to Ida Sang Hyang Widhi Wasa through art as a form of gratitude. Because, in reality, Hindu religious life has always been closely related to the elements of art, art becomes one way in practicing the teachings of Hinduism, both art as a medium of religious rites and Hinduism as inspiration and the foundation of the creation of artwork.

The next activity is to carry out a joint prayer led by a Pinandita. In the process, this prayer begins with chanting the mantra tri sandhya and performs the worship manners.

Tri sandhya in Hindu prayer activities is not just the chanting of temples alone because it contains prayers and deep meanings. The term mantra in the sense of society, especially outside Hinduism, is often communicated with negative things and tends to lead to negative mysticism, whereas, in Hinduism, the mantra has a fairly essential meaning. The term mantra means "mind form" (Titib, 2003). The term form of mind can be interpreted that mantra is a sacred speech used in worship, in mantra, there are sacred meanings where through the mind of Hindus project and focus their worship so that through this mind then Hindus form and symbolize the meaning contained in it.

"Om Papo 'ham papa karmaham, papatma papa sambavah, trahi mam pundarikaksah, sabahyabhyantarah suci" quote one of the sacred mantras in this tri sandhya has such deep meaning that Om Sanghyang Widhi
Wasa, your servant is full of suffering in deeds, soul, birth. Therefore oh Hyang widhi, save the servant from this suffering and purify the inner birth of the servant (Widana, 2020)".

Based on the quotation of one of the holy mantras tri sandhya above, it can be concluded that it contains such a deep meaning that through this mantra, Hindus, especially in this community service activity, pray to be given chastity in birth and mind. so that it can devote itself in implementing the teachings of Hinduism through educational activities, research and community service.

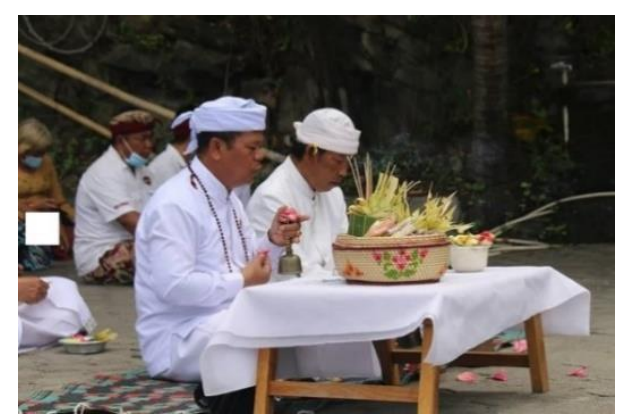

Documentation IAHN Gde Pudja Mataram

Picture 2: prayer shared by pinandita

Then continued with the manners of worship. Kramaning sembah is a series of worships in the process of worship of Hindus. This process is carried out using means of flowers or canang and incense. The process begins with praying "puyung" without means; the second prayer uses flowers addressed to Ida Sang Hyang Widhi Wasa in its manifestation as God Siva Adithya. The third prayer is done by performing flowers of various colors addressed to the gods, especially the gods who sthana in Batu Bolong Temple as a form of prostration bhakti and asked and gave thanks; the fourth prayer again uses various flowers, or kewangen addressed to all gods and goddesses who aim to ask for grace, and finally worship "puyung".

One of the mantras in the commonly chanted prayer manners is "Om anugraha manoharam Deva datta nugrahaka Arcanam sarva pujanam Namah sarva nugrahaka Deva devi mahasiddhi yajnangga nirmalatmakam Laksmi siddhisca dirgahayuh Nirvighna sukha vrddhisca," which means "O Lord, you 
are the one who attracts the gift giver. Devata award, the worship of all worship. I worship you as a giver of all grace. in deva and devi in the form of sacred yadnya. Happiness, perfection, longevity. Free from obstacles, joy and spiritual and temporal progress (Widana, 2020)".

From the meaning of the mantra above, it can be concluded that the purpose of mutual worship in this community service activity as a form of implementation of the concept of parhyangan is gratitude, and more profound is to ask for the gift of chastity of birth and mind to realize the primary purpose of Hindus namely Moksartham jagadita ya ca iti dharma. So it can be concluded that the implementation of tri hita Karana in the concept of a harmonious and harmonious relationship to God in community service activities is carried out by carrying out mutual worship.

Starting with ngayah dance Rejang renteng and prayer together that has the purpose and meaning of gratitude throughout the academic community IAHN Gde Pudja Mataram. Because it has gone smoothly and successfully changed the form of institutions and a deeper essence is a tribute to Ida Sang Hyang Widhi Wasa. Through bhakti worship and asking for grace for the peace of man, living beings, and the entire universe through birth and inner sanctity to realize the primary purpose of Hindus is Moksha.

\section{Pawongan conception in community service activities}

The second conception in tri hita Karana implemented in this community service activity is pawongan. The term pawongan refers to the word 'wong' in ancient Javanese language, meaning person or human. Pawongan concept has the meaning of the harmonious and harmonious relationship between humans and humans (Budiantara, 2017).

The concept of pawongan essentially has the sense that in seeking happiness, man must make it happen. Not only with religious rites addressed to God alone, but also how people establish good, harmonious relationships with fellow human beings. To get happiness and peace of living in the world. Because essentially man as an individual being cannot live alone without the help of another human being. Because each human being has his role, In social interaction, these roles will interact with each other and form the social process itself. So that by building a sense of brotherhood among fellow human beings will realize harmonious happiness.

In the context of pawongan as a harmonious relationship between humans, it is known the term tat twam asi and Vasudeva kutumbhakam. The meaning of that twam asi comes from Sanskrit, which means I am you, and you are me. And all the brothers (Mertayasa, 2020). This concept teaches that man's position is equal because of God's fellow beings. Through this equality, people should realize that the lives of their fellow human beings must always be harmonious and harmonious.

In this community service activity, the concept of pawongan is implemented through dharma Tula activities. This activity is carried out to deepen and strengthen insights on the concept of tri hita Karana, both macro and micro. So that the participants of community service activities understand the nature and essence of the teachings of tri hita Karana. So that not only teaches that positions on the theoretical level alone but how this understanding can be done at the practical level.

The term dharma Tula is one of the methods of implementing Hindu teachings in the concept of sad dharma. Sutriyanti (2019) explained that "Dharma Tula is the implementation of teaching by holding discussions in the classroom," which is the dissemination of Hindu teachings through an in-depth discussion process between the resource person and the audience (Sutriyanti et al., 2019). So it can be interpreted that the dharma Tula method is the process of deepening and implementing Hindu teachings through dialogue and in-depth discussion by the source.

Dharma Tula in community service activities is conducted through in-depth discussions 
about the conception of tri hita Karana value in Hindu life. Dharma Tula itself was followed by all participants of devotion with three speakers who are all lecturers from IAHN Gde Pudja Mataram and conducted indepth through discussion and question and answer.

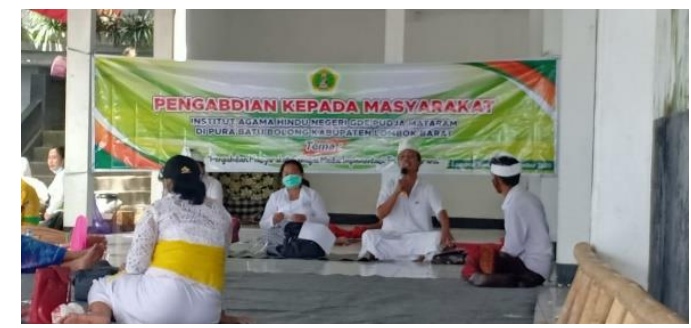

Documentation I Wayan Agus Gunada

Picture 3. Dharma Tula on the conception of tri hita Karana by three speakers

In general, the first speaker mentioned that implementing the conception of tri hita Karana socio-religiously is a concept of balance. This concept of balance essentially refers to the pattern and attitude of selfevaluation, which means that tri hita Karana is a Hindu teaching that emphasizes that balance will be created if there is selfevaluation and self-awareness. The implementation of the concept of tri hita Karana is carried out and applied at certain moments. However, it must be done through behavior in daily life and based on Hindu religious literature.

In general, the second speaker explained that the conception and implementation of the value of tri hita Karana are limited to conception but must be applied to go to a jagadhita society. It means that the implementation of the teaching aims to gain happiness through the harmonization of relationships to God, man, and the environment. So that it creates a diversity of birth and mind. In the concept of self, the tri hita Karana in the self is symbolized in the teachings or concepts of tri angga.

The third speaker mentioned that the conception of tri hita Karana is a concept of balance that is expected to realize prosperity and happiness. The conception of tri hita Karana in the microstate is human in the essence of tri angga. The main angga on the head is a symbolization of parhyangan. Madyama angga on the body as pawongan and nista angga on the feet as palemahan. While in the macro conception related to the social life of tri hita Karana in the concept of tri angga, namely the main angga as parhayangan is found in the temple located in the village, namely Pura Puseh, Pura Desa, and Dalem. Madyama angga as pawongan is the community itself. Nista angga as palemahan one of them is a cemetery and environment.

In practice, the implementation of tri hita Karana in pawongan conception in the village community. They are conducted to understand how to behave to create good social interaction in the community environment. These behaviors include thinking, saying, and doing good. Then it will create a social order that can build a society that respects and harmonizes.

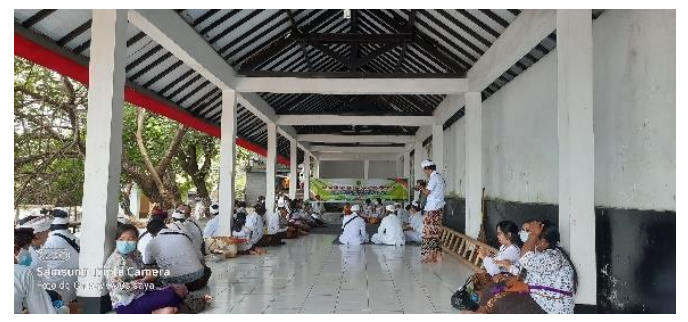

Documentation I Wayan Agus Gunada

Picture 4. Dharma Tula activities attended by community service participants

In addition, the implementation of pawongan elements in religious life in Lombok as a form of inter-religious interaction, seen in the social life of the plural Lombok community. The majority of Muslims and a small minority of Hindus, Christians, Catholics, Buddhists, and Confucians. Of course, these differences can be social capital, but a little will not trigger conflicts between religious people. However, tolerance of religion must be the key to realizing social harmony.

Zaenuri (2011) mentions that in principle with Lombok is a 'religious' area. The majority of its people convert to Islam and, side by side with other people tends to have such a high potential for conflict. So it takes community participation from all elements to maintain social harmony to reduce social 
conflicts that occur (Zaenuri, 2011).

This condition of social harmony to build a life that is in harmony between religious people, as a form of implementation of pawongan conception, is seen in the procession of war topat, which becomes a form of harmony of Hindu and Islamic interaction. topat war is a tradition of society in the form of religious rituals performed by Muslims and Hindus. It has a purpose to obtain blessings from God. The essence of the tradition of social-cultural topat war as a tradition can be a momentum to realize the harmonization of relations between religious people in Lombok in establishing brotherhood, unity, and peace in Lombok (Jayadi et al., 2017).

The realization of harmonization of religious life in Lombok, especially in the tradition of war topat, is a tradition carried out through social interaction based on cross-cultural communication. Communication becomes the basis in the realization of religious harmony both Muslims and Hindus through time factors, intermediation, and the value of religious teachings (Sari et al., 2019). Wirata (2018) explained that maintaining the stability of religious life in Lombok must be done through various efforts. Among them are eliminating feelings of suspicion, not marginalizing a person, appreciation, and respect between religious people, and eliminating discrimination against other religions (Wirata, 2018).

\section{The conception of palemahan in community service activities}

Palemahan in community service is the last conception in the teachings of tri hita Karana. Palemahan conceptually comes from the Kawi language, which is 'lemah'. In essence, palemahan has the meaning of a harmonious relationship between human and environmental nature (Budiadnya, 2018). So, in essence, the concept of palemahan has a meaning in aligning relationships to obtain happiness; the relationship is directed to God and man alone and done to the natural environment because it is undeniable that humans live in nature and coexist with nature.
Because it is side by side with nature, it becomes an obligation for humans to preserve the natural environment because, in reality, human life depends on nature. There is no denying that this fact is a reciprocal process in which humans take care of nature, and nature will benefit humans.

In this community service activity, palemahan implementation is carried out by conducting clean-up activities around the Batu bolong temple area. This activity is a form of simple implementation to take care of nature so that there is a balance of human relationship with nature by establishing a harmonious relationship, more so in the natural environment where there is worship parhyangan Ida Sang Hyang Widhi Wasa in it.

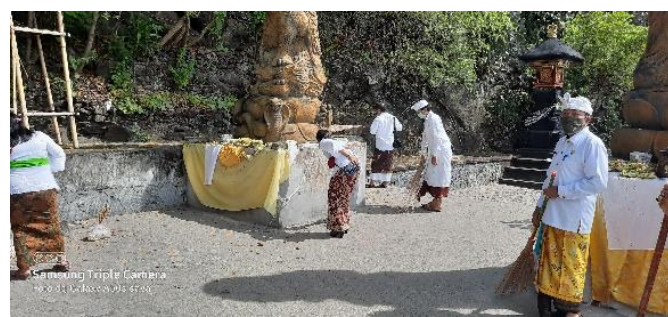

Documentation I Wayan Agus Gunada

Picture 4. Cleaning activities around The Batu Bolong Temple area

Conceptually, Hinduism focuses religious behavior on the offering side to God However, in practice, religious behavior in Hinduism also glorifies nature through the preservation processes of religious rites and practices outside of religion. This substance then directs Hindus to glorify nature and give alms to humans as a form of sraddha and bhakti of the people. this essence then gives rise to the concepts of sad kertih rites, conceptions of sad kertih in Balinese Purana lontar, namely Atma kertih, wana kertih, Danu kertih, Sagara kertih, Jana kertih, and Jagat kertih (Wiana, 2018).

Through clean-up activities in Pura Batu Bolong as a series of implementation of the concept of palemahan is a form of realization of natural environmental conservation efforts by Civitas Akademika IAHN Gde Pudja Mataram. Through this clean-up activity is embodied in the framework of macro 
understanding. However, micro-clean-up symbolizes strengthening understanding in the human self-state to understand building behavior to preserve nature continuously. Both the natural cleanliness of the buana agung environment and the cleanliness of buana alit yourself. Because in Hindu belief, the universe that is buana agung is also symbolized in human beings in buana alit. Because the human self-forming elements of Panca Maha Bhuta are elements of nature.

So it can be concluded that the implementation of palemahan in community service activities in Batu Bolong Temple, carried out with clean-up activities around the temple area. As a form of environmental nature conservation, to always be able to live in harmony with nature is the embodiment of bhakti to God Almighty.

\section{CONCLUSION}

The conceptions and sacred values in the teachings of Tri hita karana must be studied and interpreted, but they must be applied and implemented at a contextual level. This conception is noble teaching that provides learning that to get happiness, it must be done by harmonizing the relationship between humans and God, humans and humans and humans with the environment. In general, the implementation of activities to the community as a form of implementation of the tri hita karana teachings has run smoothly and well through the process of praying together to harmonize the relationship with God as a symbol of devotion. Dharma Tula activities as a form of learning and strengthening understanding through indepth discussions with resource persons so that each participant understands and understands the importance of the tri hita karana conception, and finally carries out mutual cleaning around the temple area as a form of environmental conservation efforts so that it looks clean and comfortable as a form of human harmonization with the environment. In the future, it is hoped that the implementation process of the tri hita karana teachings will continue to be carried out to create a harmonization of life towards inner and outer happiness moksartham jagaditha ya ca iti dharma

\section{REFERENCE}

Budiantara, I. K. D. (2017). Implementasi Ajaran Tri Hita Karana pada Masyarakat Hindu di Desa Sengkidu Kecamatan Manggis Kabupaten Karangasem. Lampuhyang, 8(2), 1-26. https://doi.org/10.47730/jurnallampuhy ang.v8i2.64

Budiasa, I. M., Subandia, I. M., Sukrawati, C. 1stri N., \& Ekatini, N. P. (1997). Konsep Budaya Bali Dalam Geguritan Sucita Subudhi. In Drs. Djamari (Ed.), Pusat Pembinaan dan Pengembangan Bahasa Departemen Pendidikan dan Kebudayaan (1st ed.). Pusat Pembinaan dan Pengembangan Bahasa Departemen Pendidikan dan Kebudayaan. http://repositori.kemdikbud.go.id/3076/

Creswell, J. W. (2015). Penelitian Kualitatif dan Desain Riset Memilih di antara Lima Pendekatan (Saifuddin Zuhri Qudsy (ed.); 3rd ed.). Pustaka Pelajar.

Damayanti, S. P., \& Bagiastra, I. K. (2019). Fasilitas Pendukung Destinasi Wisata Religi di Kawasan Senggigi Lombok Barat 2018. Media Bina Ilmiah, 13(6), 1281-1292.

https://doi.org/10.33758/mbi.v13i6.203

Giri, I. M. A. (2018). Intervensi Keluarga Dalam Pranata Agama Dalam Konteks Peradaban Hindu. Purwadita: Jurnal Agama Dan Budaya, 2(1), 60-70. http://jurnal.stahnmpukuturan.ac.id/inde x.php/Purwadita/article/view/22/21

Gunada, I. W. A. (2020). Ajaran Agama Hindu Dalam Geguritan Candrabherawa Sebagai Penguatan Pendidikan Karakter. Kamaya: Jurnal Ilmu Agama, 3(2), 102-119. https://doi.org/10.37329/kamaya.v3i2.4 34

Haryani, E. (2016). Menebar Spiritualitas, Menjaga Budaya: Peran Rohaniwan Asing dalam Dinamika Kehidupan Keagamaan di Bali. Harmoni, 15(2), 8195.

https://jurnalharmoni.kemenag.go.id/ind 
ex.php/harmoni/article/view/32

Haryati, N. M., \& Putra, I. G. G. (2019). Tari

Rejang Renteng Sebagai Motivasi

Belajar Tari Wali Bagi Wanita Di Kota

Denpasar. Segara Widya, 7(2), 145-155.

https://doi.org/10.31091/sw.v7i2.726

Jayadi, S., Demartono, A., \& Kartono, D. T.

(2017). Interaksi Sosial Umat Hindu dan

Muslim dalam Upacara Keagamaan dan

Tradisi Perang Topat di Lombok. Jurnal Analisa Sosiologi, 6(2), 54-63. https://doi.org/10.20961/jas.v6i2.18466

Jayendra, P. S. (2017). Ajaran Catur Marga

Dalam Tinjauan Konstruktivisme Dan

Relevansinya Dengan Empat Pilar

Pendidikan UNESCO. Vidya Samhita:

Jurnal Penelitian Agama, 3(1), 73-84.

http://ejournal.ihdn.ac.id/index.php/vs/a rticle/view/329

Mertayasa, I. K. (2020). Tat Twam Asi :

Landasan Moral Untuk Saling Asah, Asih Dan Asuh. In Beragama Dalam Damai (pp. 85-100). Jayapangus Press Book.

http://jayapanguspress.penerbit.org/inde x.php/JPB/article/view/527

Mustawan, M. D. (2020). Implementasi Ajaran Tri Hita Karana dalam Pendidikan Agama Hindu Siswa SDN Petungsewu Dusun Codo Desa Petungsewu Kecamatan Wagir Kabupaten Malang. Widya Aksara, 25(2), 198-207. http://ejournal.sthdjateng.ac.id/index.php/WidyaAksara/art icle/view/124

Nala, I. G. N., \& Wiratmadja, I. G. K. A. (1991). Murddha Agama Hindu (1st ed.). PT. Upada Sastra.

Pradnyana, G. B. M. S., Sugita, I. W., \& Mastini, G. N. (2018). Geguritan Begawan Dharma Swami (Kajian Nilai Pendidikan Agama Hindu). Jurnal Penelitian Agama Hindu, 2(2), 552-558. https://jayapanguspress.penerbit.org/ind ex.php/JPAH/article/view/1191

Rahayu, N. K. intan. (2020). Makna Simbolik Umat Hindu Dalam Persembahyangan Bulan Purnama di Kecamatan Basidondo Kabupaten Tolitoli. Jurnal Bahasa Dan Sastra, 5(1), 145-157. http://jurnal.untad.ac.id/jurnal/index.ph $\mathrm{p} / \mathrm{BDS} /$ article/view/12472

Saitya, I. B. S. (2020). Tri Hita Karana dalam Teks Agastya Parwa. Sphatika: Jurnal Teologi, 11(1), 13-21. https://doi.org/10.25078/sp.v11i1.1491

Sari, W. P., Paramita, S., \& Azeharie, S. (2019). Harmony In Intergroup Communication Between Muslim And Hinduism In Lombok. Jurnal Penelitian Komunikasi Dan Opini Publik, 23(1), 63-75.

https://doi.org/10.33299/jpkop.23.1.167 4

Sugiyono. (2020). Metode Penelitian Kualitatif Untuk Penelitian yang bersifat: Eksploratif, Enterpretif, Interaktif dan Konstruktif (S. Y. Suryandari (ed.); 1st ed.). ALFABETA.

Sunny, M. P. (2018). Pentingnya Penerapan Etika Kepemimpinan Hindu Di Bali Berlandaskan Asta Bratadengan Berbasis Tri Hita Karana. Vidya Mertta, 1(2), 84-93. https://doi.org/10.32795/vw.v1i2.192

Sutriyanti, N. K., Marsono, M., \& Alit Supandi, I. N. (2019). Sad Dharma As A Learning Method Of Hindu Religious Education And Character Of 2013 Curriculum In SMP Gurukula Bangli. Vidyottama Sanatana, 3(1), 109. https://doi.org/10.25078/ijhsrs.v3i1.650

Titib, I. M. (2003). Teologi dan SimbolSimbol dalam Agama Hindu (1st ed.). Paramita.

Wahyuni, I. A. K. S., \& Putra, A. A. N. M. (2020). Uniformisasi Pementasan Tari Rejang Renteng dan Semangat Perempuan Melestarikan Seni Budaya. Vidya Mertta, 3(1), 63-70. https://doi.org/10.32795/vw.v3i1.668

Wiana, I. K. (2018). "Sad Kertih": Sastra Agama, Filosofi, dan Aktualisasinya. Jurnal Bali Membangun Bali, 1(3), 169180.

https://doi.org/10.51172/jbmb.v1i3.29

Widana, I. G. K. (2020). Etika Sembahyang Umat Hindu (I. B. P. E. Suadnyana (ed.); 1st ed.). UNHI Press. http://repo.unhi.ac.id/jspui/bitstream/12 
3456789/1260/1/Etika Sembahyang Umat Hindu.pdf

Wirata, W. (2018). Harmonisasi Antar Umat Beragama di Lombok. Pangkaja: Jurnal Agama Hindu, 21(1), 74-79. https://ejournal.ihdn.ac.id/index.php/PJ AH/article/view/545

Yasa, I. M. A. (2021). Optimalisasi Pengabdian Masyarakat Pada Sekolah PAUD Binaan. Selaparang: Jurnal Pengabdian Masyarakat Berkemajuan, 4(2), 179-187. https://doi.org/10.31764/jpmb.v4i2.438 7

Zaenuri, A. L. (2011). Tantangan Kehidupan Beragama Di Lombok. Jurnal El-Hikam, 4(2), $61-78$ http://ejournal.kopertais4.or.id/sasambo/ index.php/elhikam/article/view/1886 